\title{
Solitary juvenile xanthogranuloma in the upper cervical spine: case report and review of the literatures
}

\author{
Dong Cao $\cdot$ Junming Ma $\cdot$ Xinghai Yang $\cdot$ \\ Jianru Xiao
}

Received: 17 September 2007/Revised: 26 December 2007/ Accepted: 29 December 2007/Published online: 29 January 2008 (c) Springer-Verlag 2008

\begin{abstract}
Solitary juvenile xanthogranuloma (JXG) in the spinal column is extremely rare and there has been no report of such a lesion involving $\mathrm{C} 1$ and $\mathrm{C} 2$ in English literature so far. Here, we report and characterize the first case of xanthogranuloma of the upper cervical spine. This case report draws attention to the fact that solitary xanthogranuloma should be considered among possible diagnoses of spinal tumor in children and young adults. An 18-year-old female patient presented to the hospital with intermittent pain in the right side of the neck. MRI studies revealed a huge soft tissue mass to the right side of the $\mathrm{C} 1$ and $\mathrm{C} 2$ vertebras, and osseous destruction can be found in the cervical spine CT scan. Complete surgical removal of the tumor and occipital-cervical instrumentation with autogenous bone graft were performed with no complications. The patient was free of pain immediately after the surgery with intact neurological functions. Follow-up MRI 6 and 12 months after the surgery showed no residue or recurrence of the tumor. Our report and the literature review indicate that isolated JXG does not show any predilections of localization inside the central nervous system. So a solitary xanthogranuloma should be considered among possible diagnoses of spinal tumor in
\end{abstract}

Each author's involvement in the production of the manuscript: Cao Dong, in charge of the whole preparation and submission process of this article. Ma Junming, in charge of the gathering of the clinical data. Yang Xinghai, in charge of the editorial work of the article. Xiao Jianru, chief of all the clinical and editorial work, the one who contributes most in the publication of this article.

D. Cao $\cdot$ J. Ma $\cdot$ X. Yang $\cdot$ J. Xiao $(\bowtie)$

Spinal Tumor Group, Department of Orthopaedics Surgery,

Changzheng Hospital, Second Military Medical University,

Shanghai 200003, China

e-mail: cdeastward@hotmail.com susceptible patients. Localized JXG shows isointense signals in MRI and enhances homogeneously with gadolinium. Immunohistochemical studies can ensure the diagnosis. Whenever possible, total surgical removal alone seems to be curative.

Keywords Juvenile xanthogranuloma .

Cervical spine tumor . Total resection

\section{Introduction}

Xanthogranuloma is a proliferative disorder of non-Langerhans histiocytes [4]. In the vast majority of cases, xanthogranulomas occur as multiple, self-limited, cutaneous lesions of children in the first two decades of life, and thus have been defined as juvenile xanthogranuloma (JXG) [7, 12]. Extracutaneous manifestations of JXG are uncommon, and isolated JXG involving the spinal column is extremely rare [5]. Here, we report and characterize a case of solitary JXG in the upper cervical spine, which to the best of our knowledge is the first JXG case in the upper cervical spine, and make a systematic review about the relevant literatures.

\section{Case report}

History and examination

An 18-year-old female patient presented to our institution with complaints of intermittent pain in the right side of the neck lasting for about 1 week. The pain exacerbated at night and worsened with motion. Resting, physical therapy, and medication had little effect in controlling the pain. 
Physical examination demonstrated a blood pressure of $120 / 70 \mathrm{mmHg}$. Inspection of the skin revealed no lesion. On palpation, a round-shaped mass could be found under the mastoid process in the right side of the neck. The mass was fixed and tenacious, with no obvious tenderness. Flexion-extension and rotation of the cervical spine were slightly limited. Superficial sensation in the right side of the neck was decreased. However, no dysesthesia appeared in other parts of the body. The results of the neurological and musculoskeletal examinations were otherwise unremarkable.

\section{Radiological studies}

CT scan of the upper cervical spine revealed a large round mass about $4.0 \times 5.0 \times 3.5 \mathrm{~cm}$ in size with osseous destruction in the right lateral masses and appendix of the $\mathrm{C} 1$ and C2 vertebras (Fig. 1). And there were irregular calcifications in the mass. MRI studies revealed a soft tissue tumor with osseous destruction in the upper cervical spine, which extended well into the surrounding structures. The tumor had a clear boundary, and the right side of the vertebral artery was enwrapped in the tumor. The tumor showed isointense to hypointense mixed signals in T1WI and T2WI, but hyperintense signals after gadolinium enhancement, with focuses of necrosis in it. The spinal cord was severely compressed at $\mathrm{C} 2$ level, but no denatured signals came out (Fig. 2).

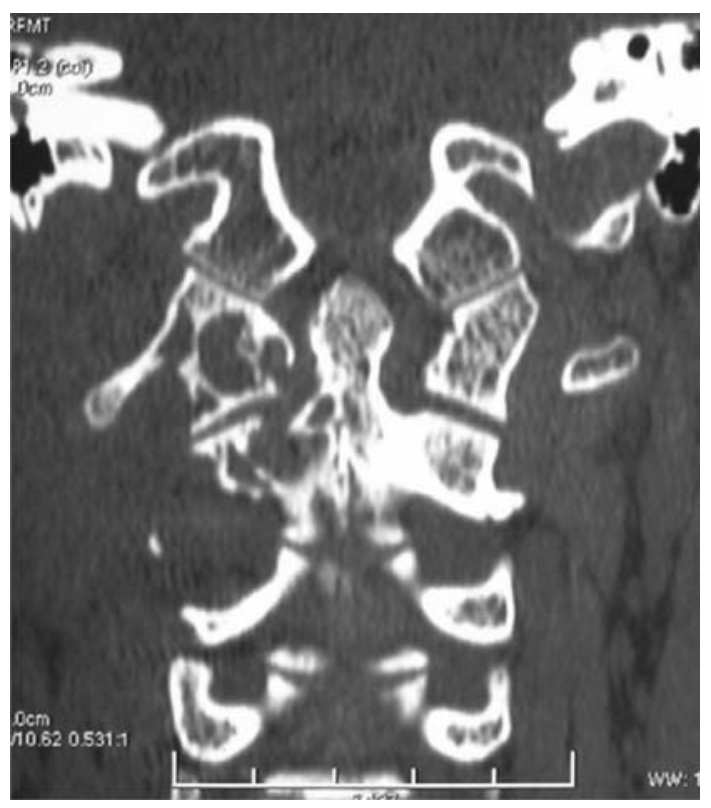

Fig. 1 Preoperative CT scan showed a large mass with osteolytic defect in the right lateral masses and appendix of the $\mathrm{C} 1$ and $\mathrm{C} 2$ vertebras

\section{Treatment}

We performed an anterior cervical spine tumor resection and a posterior occipital-cervical fusion with instrumentation for this patient. We have adopted an incision extending from the right mastoid process to submaxilla. And through this approach, a round yellowish encapsulated tumor about $4.0 \times 5.0 \times 3.5 \mathrm{~cm}$ in size was exposed. The tumor was tenacious and with limited motion. It originated from the $\mathrm{C} 2$ nerve root and involved the right lateral mass of the $\mathrm{C} 1$ and the right part of the vertebral body of the $\mathrm{C} 2$. After ligation of the right vertebral artery, the tumor was blunt dissected and subtotally removed. Then, a posterior operation was performed. The tumor was totally resected after removal of the posterior elements of $\mathrm{C} 1$ and $\mathrm{C} 2$, and then an occipital-cervical instrumentation with autogenous bone graft was performed (Fig. 3).

After surgery, the patient was relieved of pain, and could walk without difficulty. Follow-up visits have been scheduled at regular intervals to monitor the tumor recurrence and associated complications. Cervical spine MRI with gadolinium enhancement 6 and 12 months after the surgery demonstrated no residue or recurrence of the tumor (Fig. 4). Now the clinical and radiological follow-up has extended to 2 years with no relapse of the symptoms, and the patient has already returned to school.

\section{Pathology}

Gross examination showed a $4.0 \times 5.0 \times 3.5 \mathrm{~cm}$, ovoid, circumscribed, and encapsulated specimen (Fig. 5). The cut surface was homogeneous yellow. Microscopic examination revealed a xanthic appearance, with typical Touton giant cells (Fig. 6). Immunohistochemical studies showed the tumor cells were strongly inmmunopositive for CD68, CD163, and vimentin, in addition with the presence of histiocytes and multinucleated Touton giant cells, the diagnosis of Xanthogranuloma was established. Other immunohistochemical findings include: My (-), Ly (-), aAT (+), and NSE (-).

\section{Discussion}

The histiocytic disorders, first described by Adamson [1], encompass a spectrum of diseases in which the principal pathological cells are macrophages and dendritic cells [4]. $\mathrm{JXG}$ is one of the dendritic cell-related disorders, and has been classified as a non-LCH disease together with several other histiocytic entities including papular xanthoma, benign cephalic histiocytosis, sinus histiocytosis with massive lymphadenopathy (Rosai-Dorfman disease), and 
Fig. 2 Preoperative MRI scan showed osseous destruction in the right lateral masses and appendix of the $\mathrm{C} 1$ and $\mathrm{C} 2$ vertebras, and a huge mass in the soft tissue to the right side of the $\mathrm{C} 1$ and $\mathrm{C} 2$ vertebras. a Axial view, b transverse view
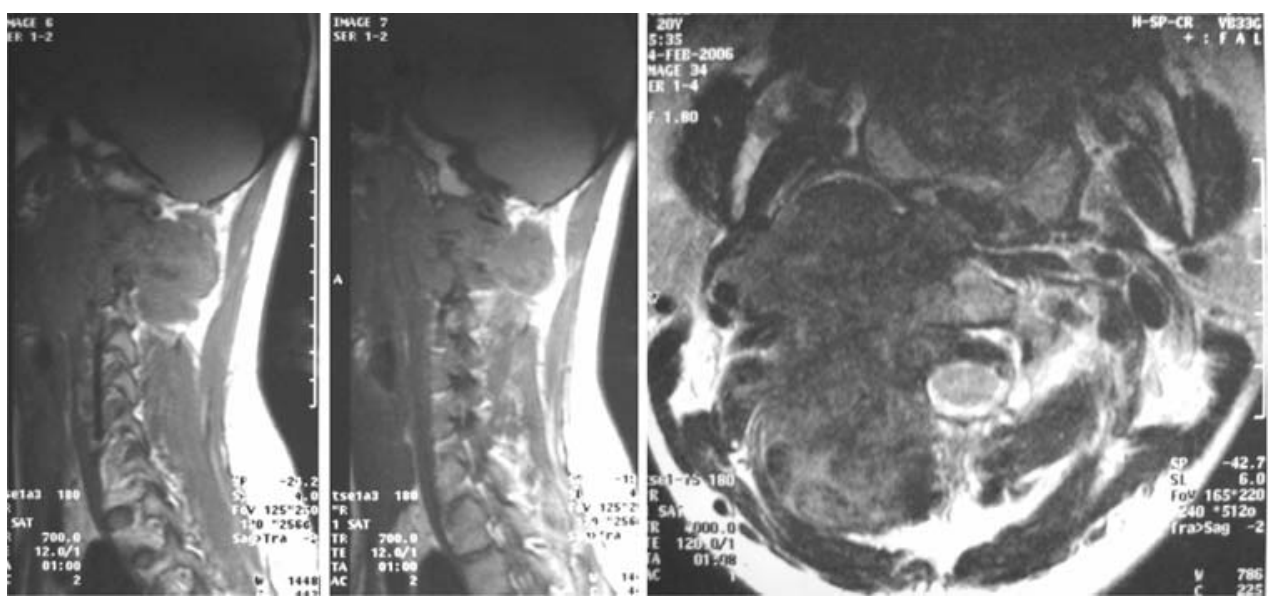

hemophagocytic histiocytosis [3]. The etiology of JXG is unknown. However, it is believed to result from a disordered macrophage response to a non-specific tissue injury, resulting in a granulomatous reaction [10].

Classic JXGs are benign, usually asymptomatic, and solitary or multiple red-to-yellowish papules and nodules composed of histiocytic cells that predominantly occur in infancy and childhood, which typically regress over several years [17]. The most frequently occurrence of the JXG lesion is on the skin of head and neck, but many extracutaneous sites have been reported. Extracutaneous involvement occurs in about $5-10 \%$ of all JXG cases. The

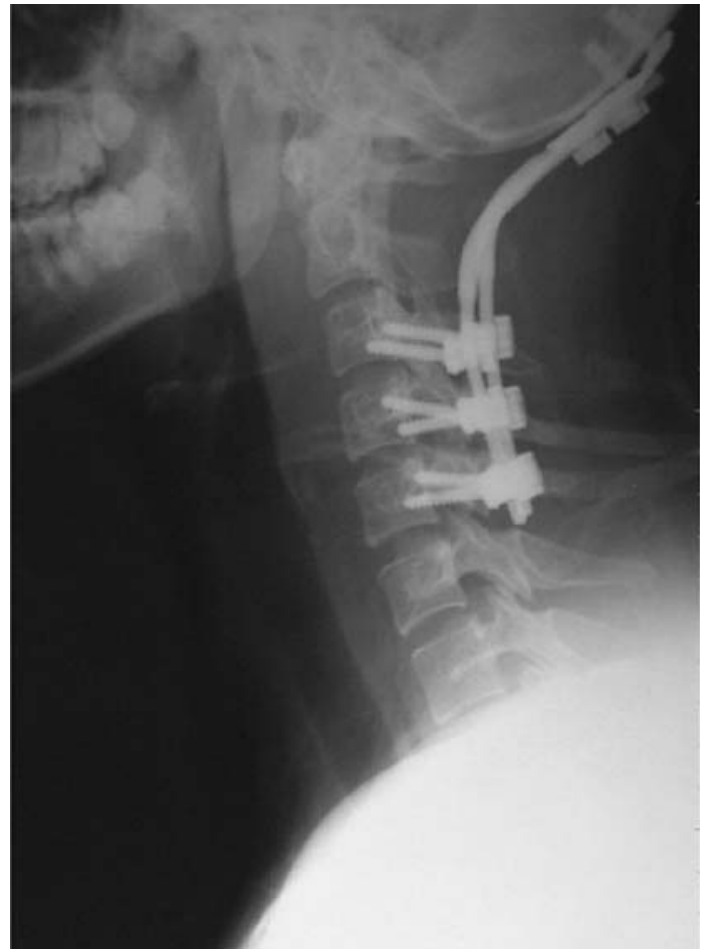

Fig. 3 Lateral view of the cervical spine after the operation of tumor resection and spine reconstruction eye, particularly the uveal tract, is the most frequent site of extracutaneous involvement. And other reported involving organs include the oropharynx, heart, lung, liver, spleen, adrenals, muscles, subcutaneous tissues, and the central nervous system, but the involvement of spine is extremely rare [2, 11, 15]. We could find only four such cases reported in English [8, 9, 15, 16] so far, and no report of a xanthogranuloma involving $\mathrm{C} 1$ and $\mathrm{C} 2$ (Table 1). The present case, to the best of our knowledge, is the first solitary JXG case involving the upper cervical spine, which originated from the $\mathrm{C} 2$ nerve root. In all xanthogranuloma cases involving the spine, the clinical features were mostly related with the anatomic localization as slow-growing tumors in general. MRI is the best method for obtaining details of the localization of the tumors and their relation to adjacent structures. The lesion may appear hypointense, isointense, or slightly hyperintense in T1WI and T2WI. And homogeneously enhancement with gadolinium can be observed in most cases.

JXG is difficult to distinguish intraoperatively with other tumors of neural origin (e.g., schwannoma, neurofibroma, nerve sheath myxoma, malignant nerve sheath tumor). Therefore, the pathological and immunohistochemical studies remain the golden standard for achieving a diagnosis of JXG. The tumor is typically a round lesion, with a yellowish to grayish appearance on the cut surface. Microscopically, a diffuse and/or nodular pattern of growth and a pushing border are apparent at low magnification. The typical cellular composition of the lesions consist one or more of the three basic cellular types: mononuclear cells, multinucleated cells with or without Touton features, and spindle cells. When present, the characteristic Touton giant cells can be found in a background of mononuclear cells. If the tumor involves the bony structure, large osteolytic lesions with well-demarcated margins can be found along with osteoclast-like giant cells that are intermixed with Touton giant cells and mononuclear cells in the bony lesions [12]. Immunohistochemistry has an important role 

study 12 months after the surgery showed no residue or recurrence of the tumor. a Axial view, $\mathbf{b}$ transverse view
Fig. 4 Postoperative MRI

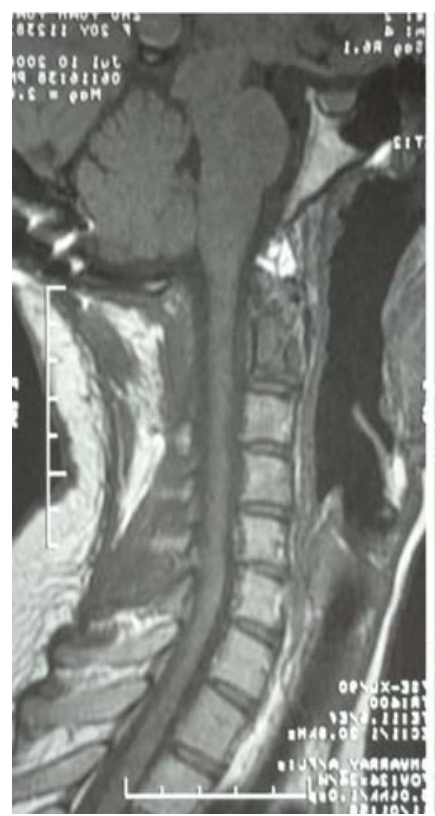

in the diagnosis of JXG. It is our experience that regardless of the cellular composition of a JXG, the mononuclear cells, giant cells, and spindle cells are consistently immunoreactive for vimentin, CD68, CD163, fascin, CD14 and factor XIIIa and non-reactive for CD1a. And in most cases, S-100 protein is also non-reactive, but scattered cells may show weak cytoplasmic reactivity, unlike the more diffuse and intense reaction of Langerhans cells [10, 12-14].

The pathological differentiation of a lesion as $\mathrm{LCH}$ or non-LCH is of considerable clinical importance. Unlike the majority of non-Langerhans histiocytoses, LCH is associated with considerable morbidity and mortality, often requiring aggressive therapy [17]. Langerhans cells are

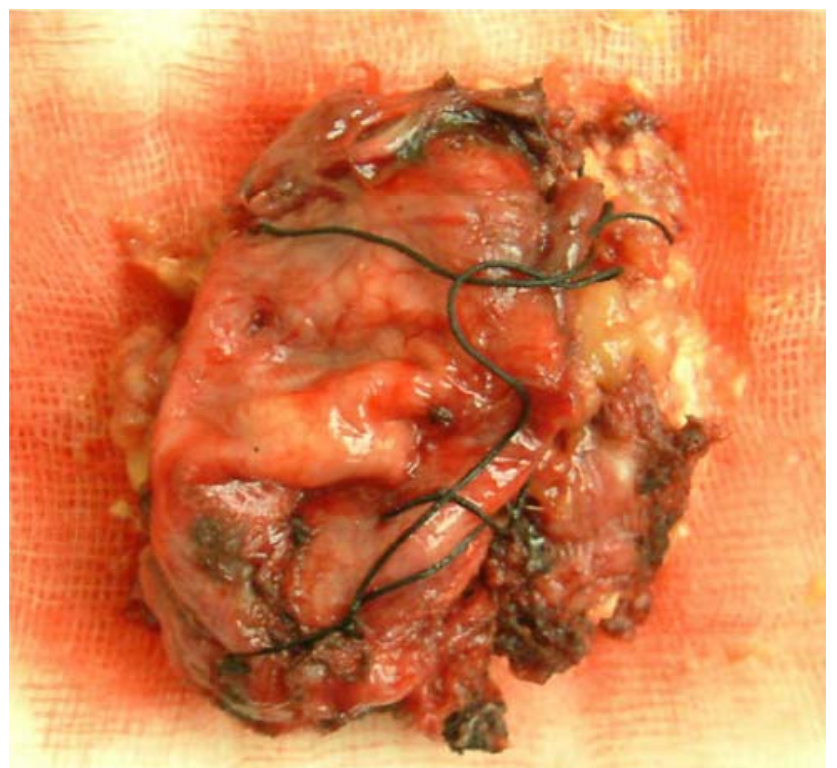

Fig. 5 Gross sample of the cervical xanthogranuloma

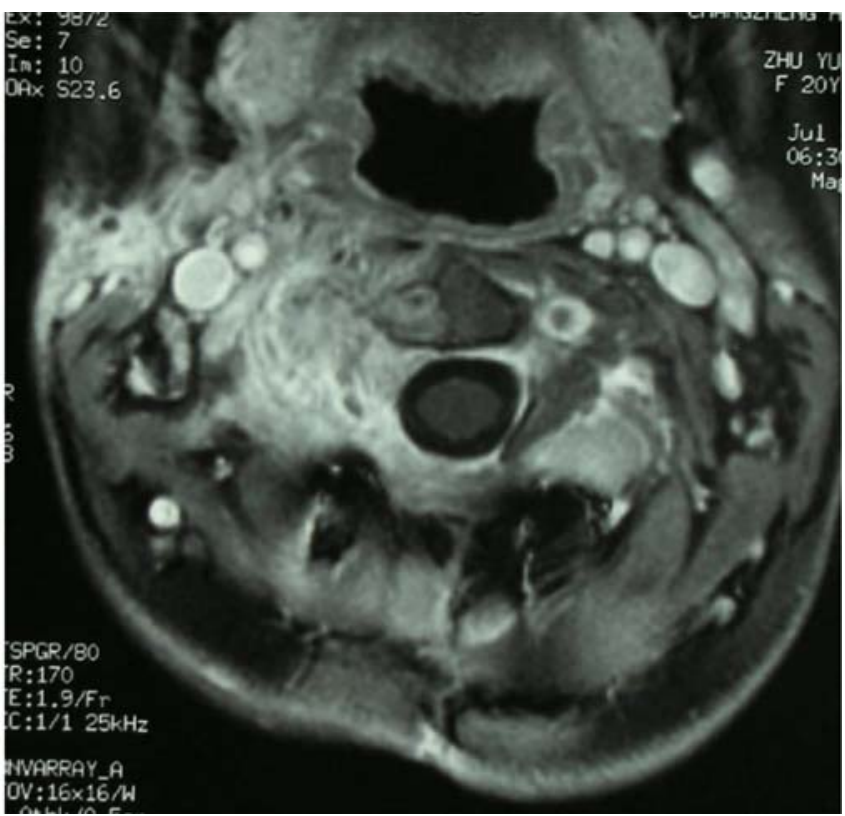

defined by the presence of Birbeck granules, which are observable in electron micrographs as pentilaminar cytoplasmic inclusions that often have a tennis racket appearance [4]. Although not diagnostic, Langerhans cells may also be identified by the presence of S-100 and CD1a staining by immunohistochemistry $[4,6]$. In the present case, none of the characteristics of Langerhans cells was observed.

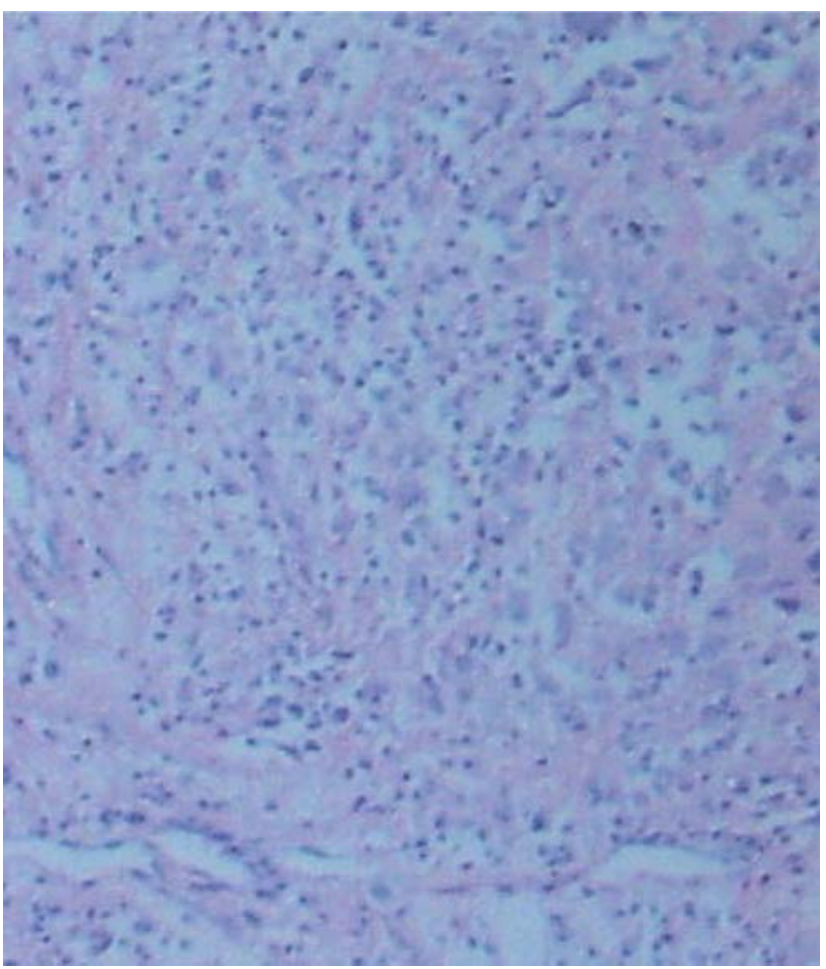

Fig. 6 Microscopical view of cervical xanthogranuloma 
Table 1 Solitary juvenile xanthogranuloma cases involving the spine reported in the literature (2007)

\begin{tabular}{|c|c|c|c|c|c|}
\hline & $\begin{array}{l}\text { Shimosawa } \\
\text { et al. [16] }\end{array}$ & Kitchen et al. [10] & Kim et al. [9] & Rampini et al. [15] & Present case \\
\hline Age & 13 months & 15 years & 16 months & 34 months & 18 years \\
\hline Sex & Female & Female & Female & Female & Female \\
\hline $\begin{array}{l}\text { Symptoms and } \\
\text { signs }\end{array}$ & $\begin{array}{l}\text { Difficult stance, } \\
\text { mild spastic } \\
\text { paraparesis }\end{array}$ & $\begin{array}{l}\text { Lower back and leg pain, } \\
\text { Lase'gue positive }\end{array}$ & $\begin{array}{l}\text { Difficult stance and } \\
\text { gait, spastic } \\
\text { paraparesis }\end{array}$ & $\begin{array}{l}\text { Intense cervical and } \\
\text { right brachial pain, } \\
\text { tetraparesis muscular } \\
\text { hypotrophy }\end{array}$ & $\begin{array}{l}\text { Intermittent pain in the } \\
\text { right side of the neck }\end{array}$ \\
\hline $\begin{array}{l}\text { Tumor } \\
\text { localization }\end{array}$ & $\begin{array}{l}\text { Intradural } \\
\text { extramedullary } \\
\text { T6-T9 }\end{array}$ & S1 nerve root sheath & $\begin{array}{l}\text { Intradural } \\
\quad \text { extramedullary } \\
\text { T1-T2 }\end{array}$ & $\begin{array}{l}\text { Intradural } \\
\text { extramedullary } \\
\text { C5-C7 }\end{array}$ & $\mathrm{C} 2$ nerve root \\
\hline CT & - & No contrast enhancement & - & - & $\begin{array}{l}\text { Irregular calcifications in } \\
\text { the mass after } \\
\text { enhancement }\end{array}$ \\
\hline MRI & $\begin{array}{l}\text { Hypointense in } \mathrm{T} 1 ; \\
\text { hypointense in } \\
\text { T2; no contrast } \\
\text { enhancement }\end{array}$ & $\begin{array}{l}\text { Isointense in } \mathrm{T} 1 ; \\
\text { hypointense in } \mathrm{T} 2 ; \\
\text { isointense in } \mathrm{DP} ; \text { no } \\
\text { contrast administered }\end{array}$ & $\begin{array}{l}\text { Isointense in } \mathrm{T} 1 ; \\
\text { hyperintense in } \\
\text { T2; homogeneous } \\
\text { enhancement }\end{array}$ & $\begin{array}{l}\mathrm{T} 1 \text { isointense; T2 } \\
\text { isointense; } \\
\text { homogeneous } \\
\text { enhancement }\end{array}$ & $\begin{array}{l}\text { Isointense to hypointense } \\
\text { in } \mathrm{T} 1 \text { and } \mathrm{T} 2 \text {, } \\
\text { hyperintense } \\
\text { enhancement }\end{array}$ \\
\hline $\begin{array}{l}\text { Surgical } \\
\text { approach }\end{array}$ & $\begin{array}{l}\text { Five-level } \\
\text { laminoplastic } \\
\text { laminectomy }\end{array}$ & $\begin{array}{l}\text { One-level laminectomy, } \\
\text { sacral-hiatus resection }\end{array}$ & $\begin{array}{l}\text { Four-level } \\
\text { laminectomy }\end{array}$ & $\begin{array}{l}\text { Four-level open-door } \\
\text { laminoplasty }\end{array}$ & $\mathrm{C} 1-\mathrm{C} 2$ laminectomy \\
\hline $\begin{array}{l}\text { Tumor relation to } \\
\text { adjacent } \\
\text { structures }\end{array}$ & $\begin{array}{l}\text { Adherent to inner } \\
\text { layer of dura } \\
\text { mater; arachnoid } \\
\text { intact }\end{array}$ & $\begin{array}{l}\text { Adherent to S1 nerve root } \\
\text { sheath }\end{array}$ & $\begin{array}{l}\text { Adherent to inner } \\
\text { layer of dura } \\
\text { mater; arachnoid } \\
\text { intact }\end{array}$ & $\begin{array}{l}\text { Adherent to inner layer } \\
\text { of dura mater; } \\
\text { arachnoid intact }\end{array}$ & $\begin{array}{l}\text { Originated from } \mathrm{C} 2 \text { nerve } \\
\text { root and involved the } \\
\text { right lateral mass of the } \\
\mathrm{C} 1 \text { and } \mathrm{C} 2\end{array}$ \\
\hline $\begin{array}{l}\text { Surgical } \\
\text { resection }\end{array}$ & Total & Total & Total & Total & Total \\
\hline
\end{tabular}

Currently, there is no standard treatment for JXG. The severity and location of the lesion dictates the course of treatment. Spontaneous regression of the skin lesions is the natural course, but in cases involving the spine, there's no regression documented so far. For such an invasive benign tumor in the upper cervical spine, total removal of the tumor seems to be curative [15]. The recurrence of the tumor is unlikely to happen after the total resection, and neurological functions can be well preserved if no damage to the neural structures had been done during the tumor resection. If total resection cannot be achieved, the patients should be followed and given close medical observation after a subtotal resection. And if the symptom recurred, a second operation may be appropriate.

Conflict of interest statement During the preparation of this article, no author has received any financial support or any other commercial associations that might pose a conflict of interest in connection with the submitted article. This article is totally the authors' own work.

\section{References}

1. Adamson HG (1905) Congenital xanthoma multiplex. Br J Dermatol 17:222
2. Bostrom J, Janssen G, Messing-Junger M, Felsberg JU, Neuen-Jacob E, Engelbrecht V, Lenard HG, Bock WJ, Reifenberger G (2000) Multiple intracranial juvenile xanthogranulomas: case report. J Neurosurg 93:335-341

3. Burgdorf WHC, Zelger B (1996) The nonLangerhan's cell histiocytosis in childhood. Cutis 58:201-207

4. Dehner LP (2003) Juvenile xanthogranulomas in the first two decades of life. Am J Surg Pathol 27(5):579-593

5. Favara BE, Feller AC, Pauli M, Jaffe ES, Weiss LM, Arico M, Bucsky P, Egeler RM, Elinder G, Gadner H, Gresik M, Henter JI, Imashuku S, Janka-Schaub G,Jaffe R, Ladisch S, Nezelof C, Pritchard J (1997) Contemporary classification of histiocytic disorders: the WHO committee on histiocytic/reticulum cell proliferations-reclassification working group of the histiocyte society. Med Pediatr Oncol 29:157-166

6. Freyer DR, Kennedy R, Bostrom BC, Kohut G, Dehner LP (1996) Juvenile xanthogranuloma: forms of systemic disease and their clinical implications. J Pediatr 129:227-237

7. George DH, Scheithauer BW, Hilton DL, Fakhouri AJ, Kraus EW (2001) Juvenile xanthogranuloma of peripheral nerve: a report of two cases. Am J Surg Pathol 25:521-526

8. Hernandez-Martin A, Baselga E, Drolet BA, Esterly NB (1997) Juvenile xanthogranuloma. J Am Acad Dermatol 36:355-369

9. Kim D, Kim T, Choi J (1996) Intradural extramedullary xanthoma of the spine. A rare lesion arising from the dura mater of the spine: case report. Neurosurgery 39:182-185

10. Kitchen ND, Davies MS, Taylor W (1995) Juvenile xanthogranuloma of nerve root origin. Br J Neurosurg 9:233-237

11. Kraus MD, Haley JC, Ruiz R, Essary L, Moran CA, Fletcher CD (2001) "Juvenile" xanthogranuloma: an immunophenotypic study with a reappraisal of histogenesis. Am J Dermatopathol 23:104-111 
12. Lesniak MS, Viglione MP, Weingart J (2002) Multicentric parenchymal xanthogranuloma in a child: case report and review of the literature. Neurosurgery 51:1493-1498

13. Nascimento AG (1997) A clinicopathologic and immunohistochemical comparative study of cutaneous and intramuscular forms of juvenile xanthogranuloma. Am J Surg Pathol 21:645-652

14. Newman CC, Raimer SS, Sanchez RL (1997) Nonlipidized juvenile xanthogranuloma: a histologic and immunohistochemical study. Pediatr Dermatol 14:98-102
15. Rampini PM, Alimehmeti RH, Egidi MG, Zavanone ML, Bauer D, Fossali E, Villani RM (2001) Isolated cervical juvenile xanthogranuloma in childhood. Spine 26:1392-1395

16. Shimosawa S, Tohyama K, Shibayama M (1993) Spinal xanthogranuloma in a child: case report. Surg Neurol 39:138-142

17. Zelger BWH, Sidroff A, Orchard G, Cerio R (1996) Non-Langerhans cell histiocytoses: a new unifying concept. Am J Dermatopathol 18:490-504 